Analytical Chemistry

Laboratory

Analytical Chemistry

Laboratory

Analytical Chemistry

Laboratory

Analytical Chemistry

Laboratory

Analytical Chemistry

Laboratory

Analytical Chemistry

Laboratory

Analytical Chemistry

Laboratory

Analytical Chemistry

Determination of Labile Copper, Cobalt, and Chromium in Textile Mill Wastewater

Laboratory

Analytical Chemistry

Laboratory

Analytical Chemistry

Laboratory

Analytical Chemistry

Laboratory

Analytical Chemistry

Laboratory

Analytical Chemistry

Laboratory

Analytical Chemistry

Laboratory

Analytical Chemistry

Laboratory

Analytical Chemistry

Laboratory

by J. S. Crain, A. M. Essling, J. T. Kiely,

E. A. Huff, D. R. Huff, and D. G. Graczyk

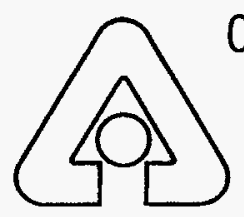

Chemical Technology Division

Argonne National Laboratory, Argonne, Illinois 60439

operated by The University of Chicago

for the United States Department of Energy under Contract W-31-109-Eng-38

Analytical Chemistry

Laboratory

Analytical Chemistry

Laboratory

Analytical Chemistry

IITRIBUTION OF THIS DOCUMENT IS UNLIMTTED

Laboratory

Analytical Chemistry

Laboratory 
Argonne National Laboratory, with facilities in the states of Illinois and Idaho, is owned by the United States government, and operated by The University of Chicago under the provisions of a contract with the Department of Energy.

\section{DISCLAIMER}

This report was prepared as an account of work sponsored by an agency of the United States Government. Neither the United States Government nor any agency thereof, nor any of their employees, makes any warranty, express or implied, or assumes any legal liability or responsibility for the accuracy, completeness, or usefulness of any information, apparatus, product, or process disclosed, or represents that its use would not infringe privately owned rights. Reference herein to any specific commercial product, process, or service by trade name, trademark, manufacturer, or otherwise, does not necessarily constitute or imply its endorsement, recommendation, or favoring by the United States Government or any agency thereof. The views and opinions of authors expressed herein do not necessarily state or reflect those of the United States Government or any agency thereof.

Reproduced from the best available copy.

A vailable to DOE and DOE contractors from the

Office of Scientific and Technical Information

P.O. Box 62

Oak Ridge, TN 37831

Prices available from (423) 576-8401

Available to the public from the

National Technical Information Service

U.S. Department of Commerce

5285 Port Royal Road

Springfield, VA 22161 


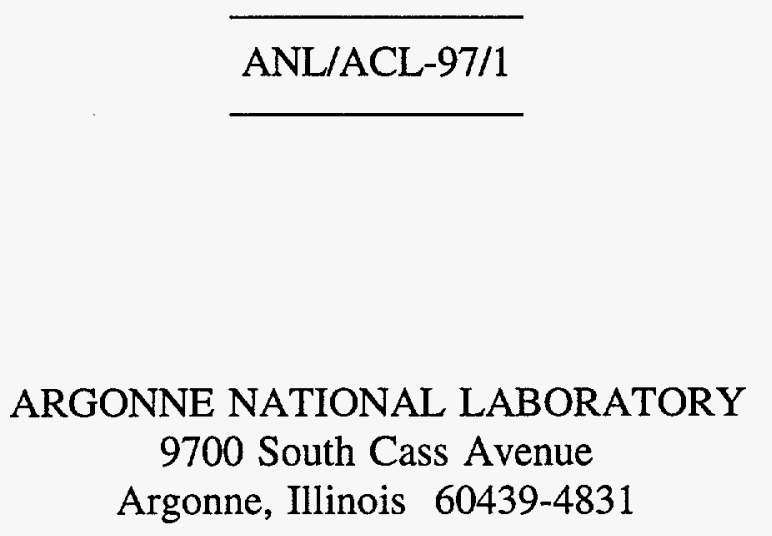

DETERMINATION OF LABILE COPPER, COBALT, AND CHROMIUM IN TEXTILE MILL WASTEWATER

by

J. S. Crain, A. M. Essling, J. T. Kiely,

E. A. Huff, D. R. Huff, and D. G. Graczyk

Analytical Chemistry Laboratory

Chemical Technology Division

\section{MASTER}

January 1997 


\section{DISCLAMMER}

Portions of this document may be illegible in electronic image products. Images are produced from the best available original docment. 


\section{TABLE OF CONTENTS}

$\underline{\text { Page }}$

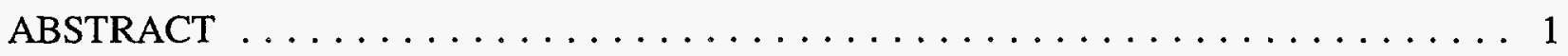

I. INTRODUCTION $\ldots \ldots \ldots \ldots \ldots \ldots \ldots \ldots \ldots \ldots \ldots \ldots \ldots \ldots \ldots \ldots \ldots$

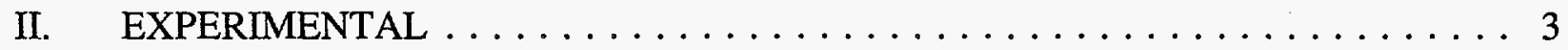

III. RESULTS AND DISCUSSION $\ldots \ldots \ldots \ldots \ldots \ldots \ldots \ldots \ldots \ldots \ldots$

A. Total Metal Determinations $\ldots \ldots \ldots \ldots \ldots \ldots \ldots \ldots \ldots$

B. Separation of Metal Species $\ldots \ldots \ldots \ldots \ldots \ldots \ldots \ldots \ldots \ldots$

C. Analysis of Metal Speciation in Field Samples ............. 9

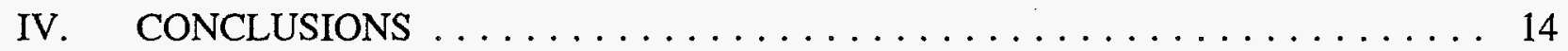

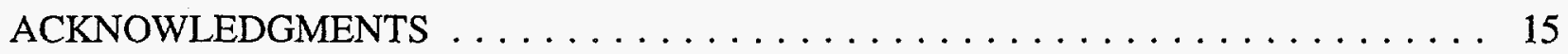

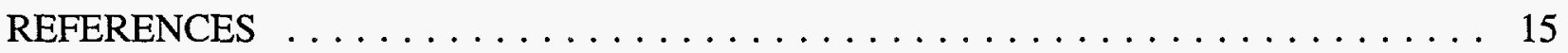

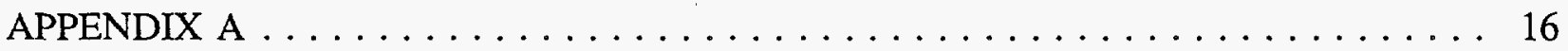

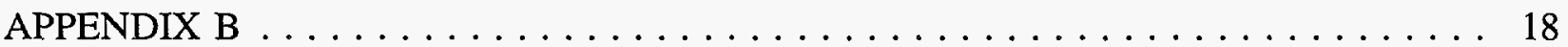




\section{LIST OF FIGURES}

No.

Title

$\underline{\text { Page }}$

1. Schematic Diagram of the Column Arrangement $\ldots \ldots \ldots \ldots \ldots \ldots \ldots$

2. Copper Retention versus [EDTA]/[Cu] Ratio for Sulfonate

Cation Exchange $(\mathrm{CatEx}) \ldots \ldots \ldots \ldots \ldots \ldots \ldots \ldots \ldots$

\section{LIST OF TABLES}

No.

Title

Page

1. Total Concentrations of Copper and Chromium in Wastewater

Effluents ................................. 6

2. Total and Separated Metal Concentrations in Effluents

of Low $\mathrm{pH}$ and Dissolved Solid Content $\ldots \ldots \ldots \ldots \ldots$

3. Total and Separated Metal Concentrations in Normal Effluents . . . . . . . . 11

4. Spike Recoveries and Mass Balances in Percent for Total

and Separated Metal Determinations 


\title{
DETERMINATION OF LABILE COPPER, COBALT, AND CHROMIUM IN TEXTILE MILL WASTEWATER
}

by

\author{
J. S. Crain, A. M. Essling, J. T. Kiely, \\ E. A. Huff, D. R. Huff, and D. G. Graczyk
}

\begin{abstract}
Copper, chromium, and cobalt species present in filtered wastewater effluent were separated by cation exchange and reverse phase chromatography. Three sample fractions were obtained: one containing metal cations (i.e., trivalent $\mathrm{Cr}$, divalent $\mathrm{Cu}$, and divalent $\mathrm{Co}$ ), one containing organic species (including metallized dyes), and one containing other unretained species. The metal content of each fraction was determined by inductively coupled plasma atomic emission spectroscopy (ICP-AES). The sum of the corrected data was compared to the metal content of a filtered effluent aliquot digested totally with fuming sulfuric acid. Other aliquots of the filtered effluent were spiked with the metals of interest and digested to confirm chemical yield and accuracy.

Method detection limits were consistently below $20 \mu \mathrm{g} \mathrm{L}{ }^{-1}$ for $\mathrm{Cu}, 30 \mu \mathrm{g}$ $\mathrm{L}^{-1}$ for $\mathrm{Co}$, and $10 \mu \mathrm{g} \mathrm{L}^{-1}$ for $\mathrm{Cr}$. Spike recoveries for undifferentiated $\mathrm{Cu}$ and $\mathrm{Cr}$ were statistically indistinguishable from unity; although Co spike recoveries were slightly low ( $-95 \%)$, its chemical yield was $98 \%$. Copper retention on the sodium sulfonate cation exchange resin was closely correlated with the $[$ EDTA] $/[\mathrm{Cu}]$ ratio, suggesting that metals retained upon the cation exchange column were assignable to labile metal species; however, mass balances for all three elements, though reasonable ( $\sim 90 \%)$, were significantly different from unity. Mechanical factors may have contributed to the material loss, but other data suggest that some metal species reacted irreversibly with the reverse phase column.
\end{abstract}




\section{INTRODUCTION}

In the environment, inorganic pollutants are inevitably ubje sted to a variety of competing chemical processes, such as precipitation, complexation, and sxida tion or reduction. Depending upon the medium, the pollutants can also be subject to bioogica I uptake, excretion, and any intermediate metabolic processes. These processes can chang the shemical form (or speciation) of the pollutant; these changes can, in turn, affect pollutant transpo $t$, the potential for metabolic uptake, and the potential for biotoxicity. Thus, knowledge asout the chemical speciation of the pollutant(s) is extremely important for accurate and rational envircnmental assessments and for development of efficient treatment or remediation strategies.

Our objective was to develop and validate a procedure for differentiating dissolved copper, cobalt, and chromium species in wastewater effluent from textile processing facilities. We decided to differentiate these species on the basis of chemical lability, which was, in this context, defined by the ability of the metal moiety to react with a sequestering medium, such as a chromatographic resin. Various sequestration media were tested using mixtures of metal cations, chelating agents, and metallized dyes, and we found that a combination of cation exchange and nonionic resins was most effective at differentiating among the various metal species. Based on our functional definition of lability, the analytical data provide a strong indication of copper, cobalt, and chromium availability for biological uptake or sequestration during effluent treatment. 


\section{EXPERIMENTAL}

Undifferentiated copper, cobalt, and chromium concentrations were determined to screen samples for significant metal content and to facilitate mass balance (i.e., quality assurance) calculations for separated versus total metal. The analytical procedure that we developed for the determination of total $\mathrm{Cu}, \mathrm{Co}$, and $\mathrm{Cr}$ is listed in Appendix $\mathrm{A}$. This procedure was used to analyze composite effluent samples that were sent to our laboratory from three textile mills (identified as MKA, DRS, and FLC). Two composite samples were taken from each site during each sampling cycle; one sample was preserved with nitric acid to $\mathrm{pH} 2$ (per regulatory requirement). All of the samples were placed in refrigerated storage upon receipt, and the analyses were completed within 180 days (also per regulatory requirement). The effect of acid preservation upon metal concentration was evaluated by comparing data from the acidified and unacidified samples.

Other unacidified composite effluent samples were shipped to our laboratory (in groups of eight over a 12-week period) under the auspices of a study funded jointly by the U.S. Environmental Protection Agency (EPA) and the American Textile Manufacturer's Institute (ATMI). These samples were analyzed immediately upon receipt. Total metals were determined in these samples using the procedure in Appendix $\mathrm{A}$, and labile $\mathrm{Cu}, \mathrm{Co}$, and $\mathrm{Cr}$ cations were separated from other species using cation exchange and reverse phase liquid chromatography in sequence. The procedure that we developed for these separations is listed in Appendix B, and a schematic diagram of the column arrangement is given in Fig. 1. 


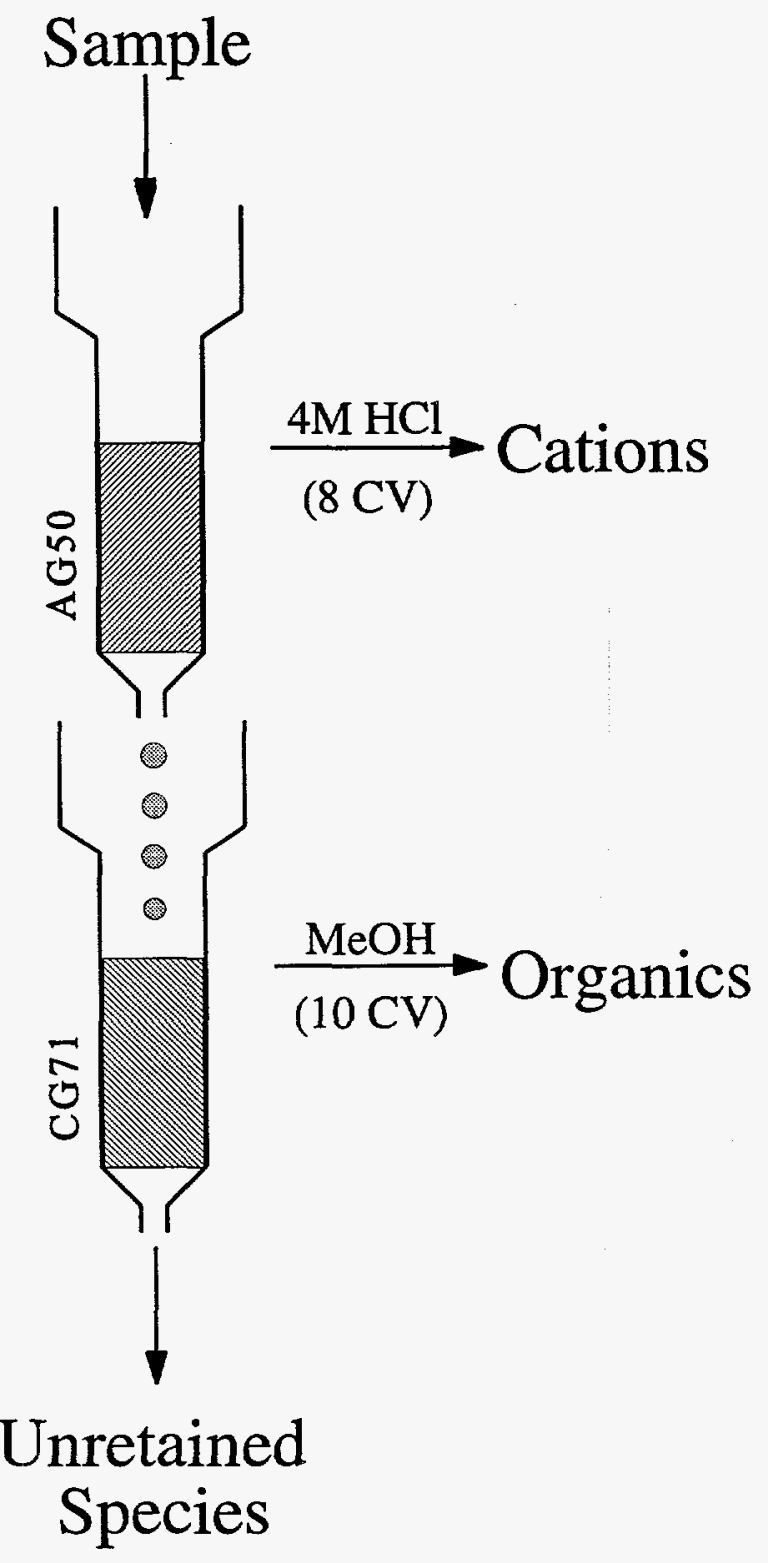

Fig. 1. Schematic Diagram of the Column Arrangement 


\section{RESULTS AND DISCUSSION}

\section{A. Total Metal Determinations}

Compositional data for the MKA, DRS, and FLC samples (including determinations of $\mathrm{pH}$ and residue upon drying) are summarized in Table 1. Copper was present in most samples at low-to-middle $\mu \mathrm{g} \mathrm{L}^{-1}$ concentrations, and chromium was detected in a few samples. Cobalt was not detected. Method detection limits were found to be $14 \mu \mathrm{g} \mathrm{L}^{-1}$ for copper, $13 \mu \mathrm{g} \mathrm{L}^{-1}$ for cobalt, and $8 \mu \mathrm{g} \mathrm{L}{ }^{-1}$ for chromium.

The recoveries for copper and chromium spikes added before and after sample digestion were indistinguishable from unity at the $95 \%$ confidence interval. These data indicate that the preparative yields were high and the atomic emission spectrometer was accurately calibrated. Duplicate copper determinations agreed with one another to within 17\% (DRS4 excepted). This level of agreement was reasonable considering that the copper content of the samples was no greater than three times the method detection limit.

Paired, two-tailed t-tests (based on the quotient of two measurements rather than their difference) were used to compare the copper content in the preserved and unpreserved samples. These copper concentrations were, on average, $14 \%$ different, and this difference was significant at the $95 \%$ confidence interval. The mass of dried residue from the acidified and unacidified samples, was, on average, $20 \%$ different (also significant at the $95 \%$ confidence interval); however, linear least-squares regression analysis indicated that the differences in copper content were not correlated with the differences in residue mass.

Copper speciation may explain this lack of correlation. For example, at $\mathrm{pH} 8$, reactions with acid-sensitive counterions (hydroxide, carbonate, or carboxylate ligands) could decrease copper availability without effecting matrix element (e.g., sodium, calcium, and magnesium) concentration. Acidification would neutralize these masking counterions and thereby release 
Table 1. Total Concentrations of Copper and Chromium in Wastewater Effluents

\begin{tabular}{|c|c|c|c|c|c|c|c|c|c|}
\hline \multirow[b]{2}{*}{ Name } & \multicolumn{5}{|c|}{ Unacidified Samples } & \multicolumn{4}{|c|}{ Acidified Samples $^{b}$} \\
\hline & $\mathrm{pH}$ & $\mathrm{TDS}, \mathrm{g} / \mathrm{L}^{\mathrm{a}}$ & $\mathrm{Cu}, \mu \mathrm{g} / \mathrm{L}$ & $\mathrm{Co}, \mu \mathrm{g} / \mathrm{L}$ & $\mathrm{Cr}, \mu \mathrm{g} / \mathrm{L}$ & TDS, $\mathrm{g} / \mathrm{L}$ & $\mathrm{Cu}, \mu \mathrm{g} / \mathrm{L}$ & $\mathrm{Co}, \mu \mathrm{g} / \mathrm{L}$ & $\mathrm{Cr}, \mu \mathrm{g} / \mathrm{L}$ \\
\hline MKA1 & 7.99 & 0.44 & 61 & $<13$ & $<8$ & 0.56 & 81 & $<13$ & $<8$ \\
\hline MKA2 & 8.07 & 0.48 & 91 & $<13$ & $<8$ & 0.60 & 103 & $<13$ & $<8$ \\
\hline MKA3 & 7.89 & 0.40 & 49 & $<13$ & $<8$ & 0.48 & 58 & $<13$ & $<8$ \\
\hline MKA4 & 8.04 & 0.60 & 45 & $<13$ & $<8$ & 0.88 & 46 & $<13$ & 10 \\
\hline MKA5 & 8.05 & 0.40 & 42 & $<13$ & $<8$ & 0.44 & 47 & $<13$ & $<8$ \\
\hline MKA6 & 8.12 & 0.48 & 26 & $<13$ & $<8$ & 0.64 & 32 & $<13$ & $<8$ \\
\hline MKA7 & 8.03 & 0.40 & 18 & $<13$ & $<8$ & 0.52 & 32 & $<13$ & $<8$ \\
\hline MKA8 & 8.19 & 0.60 & $<14$ & $<13$ & $<8$ & 0.84 & 20 & $<13$ & $<8$ \\
\hline MKA9 & 8.19 & 0.68 & 20 & $<13$ & $<8$ & 0.80 & 21 & $<13$ & $<8$ \\
\hline MKA 10 & 8.16 & 0.56 & $<14$ & $<13$ & $<8$ & 0.68 & $<14$ & $<13$ & $<8$ \\
\hline MKA11 & 8.25 & 0.48 & 42 & $<13$ & $<8$ & 0.56 & 49 & $<13$ & $<8$ \\
\hline MKA 12 & 8.16 & 0.48 & 25 & $<13$ & $<8$ & 0.52 & 21 & $<13$ & $<8$ \\
\hline MKA13 & 8.07 & 0.64 & 18 & $<13$ & $<8$ & 0.84 & 19 & $<13$ & $<8$ \\
\hline MKA 14 & 8.28 & 0.64 & 26 & $<13$ & 12 & 0.72 & 31 & $<13$ & 9 \\
\hline MKA15 & 8.31 & 0.40 & 18 & $<13$ & $<8$ & 0.52 & 25 & $<13$ & $<8$ \\
\hline MKA16 & 8.18 & 0.48 & 23 & $<13$ & $<8$ & 0.48 & 23 & $<13$ & $<8$ \\
\hline DRS1 & 8.31 & 1.40 & 60 & $<13$ & $<8$ & 1.60 & 54 & $<13$ & $<8$ \\
\hline DRS2 & 7.95 & 1.50 & 51 & $<13$ & $<8$ & 1.60 & 51 & $<13$ & $<8$ \\
\hline DRS3 & 8.20 & 1.40 & 54 & $<13$ & $<8$ & 1.60 & 49 & $<13$ & $<8$ \\
\hline DRS4 & 8.70 & 1.10 & 67 & $<13$ & $<8$ & 1.40 & 73 & $<13$ & $<8$ \\
\hline DRS5 & 8.12 & 1.40 & 57 & $<13$ & $<8$ & 1.50 & 80 & $<13$ & $<8$ \\
\hline FLC1 & 8.03 & 1.70 & 15 & $<13$ & $<8$ & 1.70 & $<14$ & $<13$ & $<8$ \\
\hline
\end{tabular}

a Total dissolved solid, i.e., the quotient of "residue upon drying" and sample volume.

${ }^{b}$ Adjusted to $\mathrm{pH} 2$ with nitric acid.

copper without raising the dissolved solid content. Depending upon lability, the acid could also leach copper from insoluble matter (e.g., fibers) which would also increase copper levels without appreciably raising dissolved solid content. 


\section{B. Separation of Metal Species}

For this project, we broadly divided metal-bearing species into three categories: cations, organometallics, and "other" species. The cation group included labile forms of $\mathrm{Cr}$ (III), $\mathrm{Cu}$ (II), and Co (II). Organometallics included metallized dyes and any other stable but largely nonpolar metal ion complexes (e.g., metal humates). Finally, "other" species included hexavalent $\mathrm{Cr}$ and any stable but polar metal ion complexes, e.g., those with ethylenediamine tetraacetic acid (EDTA). To best separate these classes of metal species, we tested a cation exchange/reverse phase liquid chromatography strategy, the final version of which is shown schematically in Fig. 1.

Preliminary studies showed that certain metallized dyes, Acid Yellow 151 and Acid Black 172 in particular, reacted irreversibly with iminodiacetate (weak acid) cation exchange resins. This condition was unacceptable so we focused our attention upon sulfonate (strong acid) cation exchangers. Metallized dyes reacted reversibly with the strong acid resin, but we found that EDTA did not attenuate copper retention on the cation exchanger to the degree we expected. (NOTE: Compared with $\mathrm{Cr}$ (III) and Co (II), formation of the Cu (II) EDTA complex is most facile under ambient conditions. $)^{1}$ We suspected that the labile hydrogen ions on the column (one per sulfonate group) caused the $\mathrm{pH}$-sensitive $\mathrm{Cu}$ (II) EDTA complex to decompose oncolumn (increasing retention) and we speculated that if the sample were buffered, local $\mathrm{pH}$ would be moderated, and better results would be obtained.

Figure 2 shows the relationship between percent copper retention and the [EDTA]/[Cu] ratio for a series of samples in $\mathrm{pH} 5$ formate buffer. This relationship was more linear and reproducible than that observed in the unbuffered samples; however, there was definitely not a 1:1 correspondence. We were also concerned that differences between the buffer $\mathrm{pH}$ and the native $\mathrm{pH}$ of the sample could change metal speciation, primarily by releasing ions bound as organic acid complexes or insoluble salts. Work done elsewhere ${ }^{2}$ suggests that if the resin were 


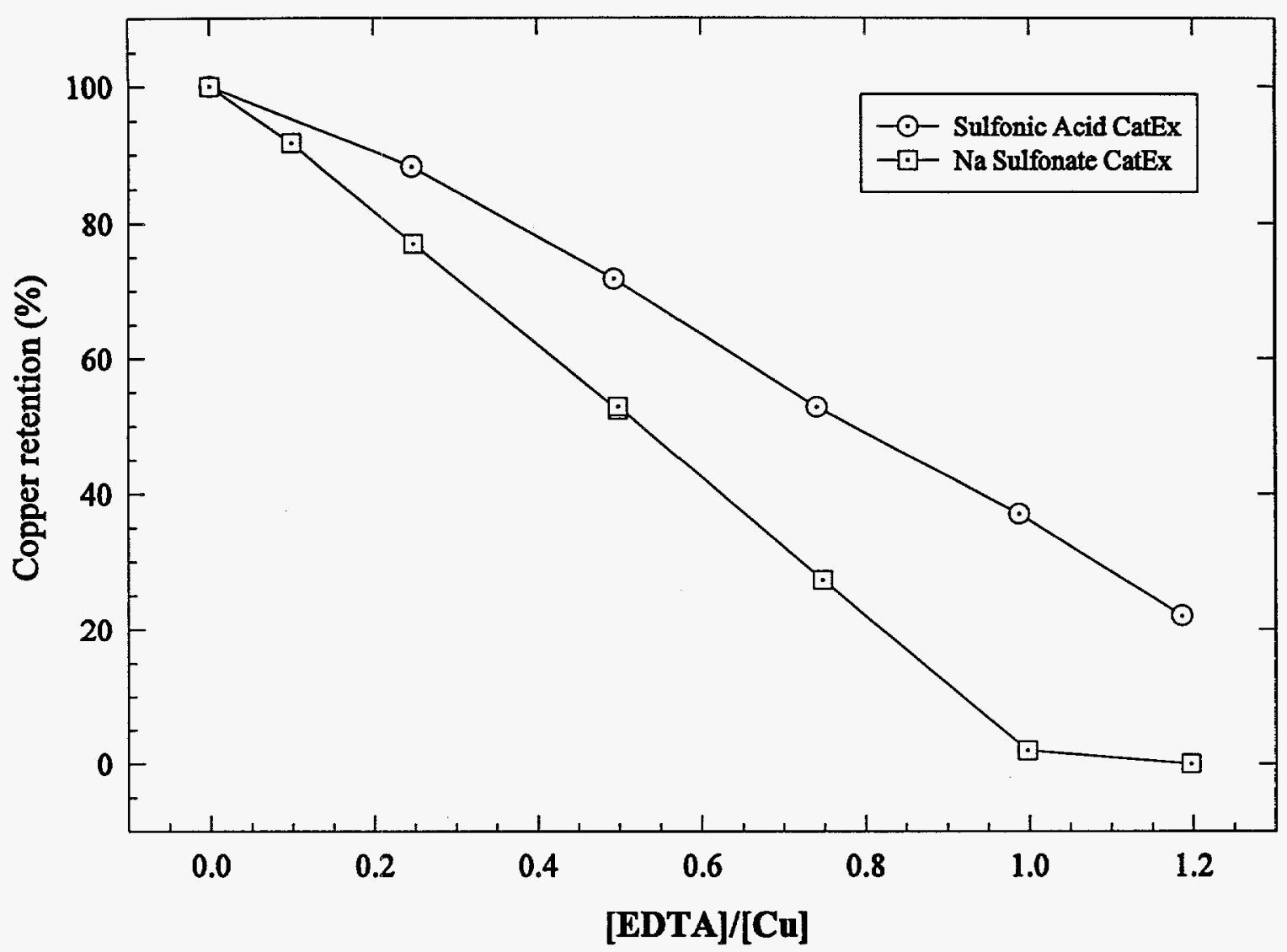

Fig. 2. Copper Retention versus $[\mathrm{EDTA}] /[\mathrm{Cu}]$ Ratio for Sulfonate Cation Exchange (CatEx)

converted to its sodium salt form, we could obtain the desired 1:1 correspondence. Therefore, we reacted the sulfonic acid resin with sodium hydroxide, rinsed the column thoroughly with water, and then repeated the experiment.

The different copper and chromium species, as well as the metallized dyes, were all satisfactorily recovered from the sodium resin column. Copper retention on the sodium resin versus $[\mathrm{EDTA}] /[\mathrm{Cu}]$ is shown in Fig. 2. It is extremely significant to note that copper retention corresponded closely with the retention expected on the basis of the $[\mathrm{EDTA}] /[\mathrm{Cu}]$ ratios in the test solutions: when $[\mathrm{EDTA}] /[\mathrm{Cu}]=0$, copper was $100 \%$ retained, whereas at $[\mathrm{EDTA}] /[\mathrm{Cu}]=1$, 
copper was not. These data suggest that when the resin is in its sodium salt form, the cation exchange process will accurately reflect the concentration of labile metals in solution.

To complete the separation process, the effluent from the cation exchange column was passed through a column of nonionic polymer resin, as shown in Fig. 1. This second separation step was necessary to differentiate organometallic species (e.g., chromium dyes) from other unretained species (e.g., chromate). The efficacy of this separation step was tested using various mixtures of copper, EDTA, and copper-bearing dyes. For sample volumes of $10 \mathrm{~mL}$ or less, the copper species were separated as expected, i.e., $\mathrm{Cu}$ (II) was quantitatively retained upon the cation exchange column, the dyes were quantitatively retained upon the nonionic resin column, and the EDTA complex was unretained by either column.

To obtain detection limits less than or equal to those of the inductively coupled plasmaatomic emission spectrometer (ICP-AES), sample volumes of $25 \mathrm{~mL}$ or greater had to be loaded on the columns. However, additional experiments indicated that organocopper species (particularly those in Direct Red 083:1 and Direct Blue 189) were not quantitatively separated from the other (e.g., anionic) metal species at these higher volumes. A longer CG71 column would have probably mitigated this problem, but funding for further method development was unavailable. Therefore, as this work continued (see below), we continued using the reverse phase (nonpolar resin) column, but we did not report data obtained as a result of the reverse phase separation.

\section{Analysis of Metal Speciation in Field Samples}

Compositional data for the EPA/ATMI wastewater samples (including determinations of $\mathrm{pH}$ and residue upon drying) are summarized in Tables 2 and 3, where "total" metal concentrations represent those obtained using the procedure in Appendix A, "labile" metal concentrations represent cations retained upon the ion-exchange column (see Fig. 1 and 
Table 2. Total and Separated Metal Concentrations in Effluents of Low pH and Dissolved Solid Content

\begin{tabular}{|c|c|c|c|c|c|c|c|c|c|c|c|}
\hline \multirow[b]{2}{*}{ Name } & \multirow[b]{2}{*}{$\mathrm{pH}$} & \multirow[b]{2}{*}{ TDS, g/L } & \multicolumn{3}{|c|}{$\underline{\mathrm{Cu}, \mu \mathrm{g} / \mathrm{L}}$} & \multicolumn{3}{|c|}{$\underline{\mathrm{Cr}, \mu \mathrm{g} / \mathrm{L}}$} & \multicolumn{3}{|c|}{$\mathrm{Co}, \mu \mathrm{g} / \mathrm{L}$} \\
\hline & & & Total & Labile & Other & Total & Labile & Other & Total & Labile & Other \\
\hline $2369 \mathrm{D}$ & 4.90 & $\mathrm{nd}^{\mathrm{a}}$ & $<3$ & $<6$ & $<5$ & 402 & $<3$ & 387 & $<9$ & $<19$ & $<14$ \\
\hline dup ${ }^{b}$ & $\mathrm{na}^{\mathrm{c}}$ & na & 14 & na & na & 405 & na & na & $<9$ & na & na \\
\hline $2369 \mathrm{~F}$ & 4.74 & nd & $<3$ & $<6$ & $<5$ & 163 & $<3$ & 143 & $<9$ & $<19$ & $<14$ \\
\hline $2803 B$ & 5.98 & nd & 461 & 10 & 461 & $<4$ & $<4$ & $<3$ & $<30$ & $<24$ & $<18$ \\
\hline $2803 C$ & 5.67 & nd & 46 & $<7$ & 58 & $<4$ & $<4$ & $<3$ & $<30$ & $<24$ & $<18$ \\
\hline $2803 F$ & 5.98 & nd & 51 & 37 & $<7$ & 48 & 38 & $<3$ & 43 & 39 & $<18$ \\
\hline $2803 G$ & 5.63 & nd & $<12$ & $<7$ & $<7$ & 60 & $<4$ & 47 & $<30$ & $<24$ & $<18$ \\
\hline $2803 \mathrm{H}$ & 5.65 & nd & 179 & $<15$ & 143 & $<3$ & $<3$ & $<4$ & $<3$ & $<20$ & $<8$ \\
\hline $\operatorname{dup}^{d}$ & na & na & na & na & na & $<2$ & $<4$ & $<4$ & $<26$ & $<30$ & $<16$ \\
\hline
\end{tabular}

a "Not detected"

${ }^{b}$ Duplicate for total metal content only.

c "Not analyzed"

${ }^{d}$ Duplicate for labile metal content only; duplicate data for $\mathrm{Cu}$ not reported due to high blanks.

Appendix B), and "other" metal concentrations represent those species retained upon the CG71 column or otherwise unretained. Copper, chromium, and/or cobalt were detected in some of the samples, and method detection limits, though variable from day to day, were consistently below $20 \mu \mathrm{g} \mathrm{L} \mathrm{L}^{-1}$ for $\mathrm{Cu}, 30 \mu \mathrm{g} \mathrm{L}{ }^{-1}$ for $\mathrm{Co}$, and $10 \mu \mathrm{g} \mathrm{L}^{-1}$ for chromium.

Spike recovery and mass balance data for these analyses are presented in Table 4. For $\mathrm{Cu}$ and $\mathrm{Cr}$, spike recoveries were statistically indistinguishable from unity at the $95 \%$ confidence interval, and chemical yields (predigestion spike over postdigestion spike) for $\mathrm{Cu}$ and $\mathrm{Cr}$ were $100 \%$. For cobalt the chemical yield was $98 \%$, but spike recoveries were low, significantly different from unity at the $95 \%$ confidence interval. These data suggest that either the cobalt determinations contained a uniform bias or cobalt concentration of the spike solution was lower than nominal. 
Table 3. Total and Separated Metal Concentrations in Normal Effluents

\begin{tabular}{|c|c|c|c|c|c|c|c|c|c|c|c|}
\hline \multirow[b]{2}{*}{ Name } & \multirow[b]{2}{*}{$\mathrm{pH}$} & \multirow[b]{2}{*}{ TDS, g/L } & \multicolumn{3}{|c|}{$\underline{\mathrm{Cu}, \mu \mathrm{g} / \mathrm{L}}$} & \multicolumn{3}{|c|}{$\underline{\mathrm{Cr}, \mu \mathrm{g} / \mathrm{L}}$} & \multicolumn{3}{|c|}{ Co, $\mu \mathrm{g} / \mathrm{L}$} \\
\hline & & & total & labile & other & total & labile & other & total & labile & other \\
\hline $2803 \mathrm{~A}$ & 5.48 & 1.2 & 200 & 186 & $<7$ & $<4$ & $<4$ & $<3$ & $<30$ & $<24$ & $<18$ \\
\hline $2803 \mathrm{D}$ & 5.23 & 1.2 & $<12$ & $<7$ & $<7$ & 208 & 178 & $<3$ & $<30$ & $<24$ & $<18$ \\
\hline $2803 E$ & 7.81 & 0.55 & 43 & $<7$ & 42 & $<4$ & $<4$ & $<3$ & $<30$ & $<24$ & $<18$ \\
\hline $2821 \mathrm{~A}$ & 7.11 & 0.39 & 68 & $<15$ & 57 & 12 & $<3$ & 4 & 39 & $<20$ & 19 \\
\hline $\operatorname{dup}^{a}$ & na & na & na & na & na & 14 & $<4$ & $<4$ & 27 & $<30$ & 23 \\
\hline $2822 \mathrm{~A}$ & 6.90 & 2.8 & $<13$ & $<15$ & $<5$ & $<3$ & $<3$ & $<4$ & $<3$ & $<20$ & $<8$ \\
\hline dup $^{a}$ & na & na & na & na & na & $<2$ & $<4$ & $<4$ & $<26$ & $<30$ & $<16$ \\
\hline $2823 \mathrm{~A}$ & 8.41 & 2.0 & 14 & $<15$ & 8 & $<3$ & $<3$ & $<4$ & $<3$ & $<20$ & $<8$ \\
\hline dup $^{2}$ & na & na & na & na & na & $<2$ & $<4$ & $<4$ & $<26$ & $<30$ & $<16$ \\
\hline $2826 A$ & 7.23 & 1.2 & 24 & $<15$ & 20 & 5 & $<3$ & $<4$ & 3 & $<20$ & $<8$ \\
\hline dup $^{a}$ & na & na & na & na & na & 3 & $<4$ & $<4$ & $<26$ & $<30$ & $<16$ \\
\hline $2830 \mathrm{~A}$ & 7.32 & 0.93 & $<13$ & $<15$ & $<5$ & 13 & $<3$ & 6 & 132 & $<20$ & 116 \\
\hline dup $^{a}$ & na & na & na & na & na & 17 & $<4$ & 8 & 136 & $<30$ & 123 \\
\hline $2833 \mathrm{~A}$ & 7.21 & 0.31 & $<13$ & $<15$ & $<5$ & $<3$ & $<3$ & $<4$ & $<3$ & $<20$ & $<8$ \\
\hline dup $^{a}$ & na & na & na & na & na & $<2$ & $<4$ & $<4$ & $<26$ & $<30$ & $<16$ \\
\hline $2835 \mathrm{~A}$ & 7.60 & 2.0 & 140 & $<15$ & 134 & $<3$ & $<3$ & $<4$ & 7 & $<20$ & $<8$ \\
\hline dup ${ }^{a}$ & na & na & na & na & na & $<2$ & $<4$ & $<4$ & $<26$ & $<30$ & $<16$ \\
\hline $2836 \mathrm{~A}$ & 7.78 & 0.94 & 85 & $<15$ & 80 & 30 & $<3$ & 26 & $<3$ & $<20$ & $<8$ \\
\hline dup $^{a}$ & na & na & na & na & na & 32 & $<4$ & 31 & $<26$ & $<30$ & $<16$ \\
\hline $2840 \mathrm{~A}$ & 7.57 & 0.96 & 15 & $<8$ & 13 & 5 & $<3$ & 4 & $<7$ & $<14$ & $<9$ \\
\hline $2841 \mathrm{~A}$ & 9.63 & 2.4 & 207 & $<8$ & 204 & $<4$ & $<3$ & $<3$ & $<7$ & $<14$ & $<9$ \\
\hline $2848 \mathrm{~A}$ & 7.30 & 0.24 & $<10$ & $<8$ & $<5$ & $<4$ & $<3$ & $<3$ & $<7$ & $<14$ & $<9$ \\
\hline $2849 \mathrm{~A}$ & 7.27 & 0.72 & $<10$ & $<8$ & $<5$ & $<4$ & $<3$ & $<3$ & $<7$ & $<14$ & $<9$ \\
\hline $2850 \mathrm{~A}$ & 5.38 & 0.56 & $<10$ & $<8$ & 7 & $<4$ & $<3$ & $<3$ & $<7$ & $<14$ & $<9$ \\
\hline $2859 \mathrm{~A}$ & 7.32 & 0.41 & $<10$ & $<8$ & $<5$ & $<4$ & $<3$ & $<3$ & $<7$ & $<14$ & $<9$ \\
\hline $2860 \mathrm{~A}$ & 7.34 & 1.7 & 32 & 11 & 15 & 13 & $<3$ & 5 & $<7$ & $<14$ & $<9$ \\
\hline $2861 \mathrm{~A}$ & 7.40 & 1.8 & 21 & $<8$ & 21 & $<4$ & $<3$ & $<3$ & $<7$ & $<14$ & $<9$ \\
\hline
\end{tabular}


Table 3. (contd)

\begin{tabular}{|c|c|c|c|c|c|c|c|c|c|c|c|}
\hline \multirow[b]{2}{*}{ Name } & \multirow[b]{2}{*}{$\mathrm{pH}$} & \multirow[b]{2}{*}{ TDS, g/L } & \multicolumn{3}{|c|}{$\underline{\mathrm{Cu}, \mu \mathrm{g} / \mathrm{L}}$} & \multicolumn{3}{|c|}{$\mathrm{Cr}, \mu \mathrm{g} / \mathrm{L}$} & \multicolumn{3}{|c|}{ Co, $\mu \mathrm{g} / \mathrm{L}$} \\
\hline & & & total & labile & other & total & labile & other & total & labile & other \\
\hline $2862 A$ & 8.30 & 2.0 & 73 & $<18$ & 71 & $<7$ & $<3$ & $<4$ & $<9$ & $<12$ & $<11$ \\
\hline $2867 \mathrm{~A}$ & 7.54 & 0.45 & $<17$ & $<18$ & $<8$ & $<7$ & $<3$ & $<4$ & $<9$ & $<12$ & $<11$ \\
\hline $2869 \mathrm{~A}$ & 7.85 & 0.74 & $<17$ & $<18$ & $<8$ & $<7$ & $<3$ & $<4$ & $<9$ & $<12$ & $<11$ \\
\hline $2872 \mathrm{~A}$ & 7.55 & 0.43 & $<17$ & $<18$ & $<8$ & $<7$ & $<3$ & $<4$ & $<9$ & $<12$ & $<11$ \\
\hline $2877 \mathrm{~A}$ & 7.77 & 0.47 & $<17$ & $<18$ & 11 & $<7$ & $<3$ & $<4$ & $<9$ & $<12$ & $<11$ \\
\hline $2884 \mathrm{~A}$ & 6.84 & 0.54 & $<17$ & $<18$ & 8 & $<7$ & $<3$ & 4 & 14 & $<12$ & $<11$ \\
\hline $2885 \mathrm{~A}$ & 7.54 & 0.80 & $<17$ & $<18$ & $<8$ & $<7$ & $<3$ & $<4$ & $<9$ & $<12$ & $<11$ \\
\hline $2893 \mathrm{~A}$ & 7.57 & 0.54 & 32 & 27 & $<8$ & $<7$ & $<3$ & $<4$ & $<9$ & $<12$ & $<11$ \\
\hline $2897 \mathrm{~A}$ & 8.44 & 1.9 & 335 & 26 & 289 & 274 & $<3$ & 264 & 133 & $<19$ & 130 \\
\hline $2898 \mathrm{~A}$ & 7.86 & 0.72 & 9 & $<6$ & 5 & 10 & $<3$ & 1 & $<9$ & $<19$ & $<14$ \\
\hline $2902 \mathrm{~A}$ & 7.70 & 0.47 & 6 & $<6$ & $<5$ & $<9$ & $<3$ & $<1$ & $<9$ & $<19$ & $<14$ \\
\hline 2914A & 7.28 & 0.65 & 19 & 12 & 8 & 10 & $<3$ & 3 & $<9$ & $<19$ & $<14$ \\
\hline $2916 \mathrm{~A}$ & 7.60 & 0.54 & 13 & 8 & $<5$ & $<9$ & $<3$ & $<1$ & $<9$ & $<19$ & $<14$ \\
\hline $2916 B$ & 5.48 & 0.36 & 9 & $<6$ & 28 & $<9$ & $<3$ & $<1$ & $<9$ & $<19$ & $<14$ \\
\hline
\end{tabular}

${ }^{2}$ Duplicate for total and labile metal content; duplicates for $\mathrm{Cu}$ not reported due to high blanks.

Table 4. Spike Recoveries and Mass Balances in Percent for Total and Separated Metal Determinations

\begin{tabular}{r|c|c|c}
\hline \multicolumn{1}{c}{$\mathrm{Cu}$} & $\mathrm{Cr}$ & $\mathrm{Co}$ \\
\hline Total Metal Digests $(n=5)$ & & & \\
Predigestion Spike & $99 \pm 3$ & $98 \pm 3$ & $93 \pm 4$ \\
Postdigestion Spike & $99 \pm 4$ & $98 \pm 4$ & $95 \pm 5$ \\
Spiked Blanks ( $n=5)$ & & & \\
Labile Metal Blank & $97 \pm 3$ & $99 \pm 3$ & $95 \pm 2$ \\
CG71 Eluate Blank & $98 \pm 6$ & $99 \pm 4$ & $96 \pm 4$ \\
Unretained Metal Blank & $98 \pm 6$ & $99 \pm 3$ & $96 \pm 3$ \\
Mass Balance & $92 \pm 9$ & $89 \pm 7$ & $90 \pm 5$ \\
$(\mathrm{n}=16)$ & $(\mathrm{n}=8)$ & $(\mathrm{n}=5)$ \\
\hline
\end{tabular}


Mass balance for all three analytes, i.e., the sum of the separated metal concentrations over the total metal concentration, was also uniformly low and significantly different from unity at the $95 \%$ confidence interval. The mass balance data were compiled using only those samples that contained twice the method detection limit or greater of the metal, and outlying data were rejected with $95 \%$ confidence using Dixon's $Q$ test. ${ }^{3}$ The element-to-element variations in the mass balance data were insignificant at the $95 \%$ confidence interval (based on one-way ANOVA), which suggests that mechanical factors (such as incomplete rinsing of the column void volume) may have played a role in the underrecovery. However, this conclusion is not supported by observation; for example, we found that most colored species were eluted very rapidly from the CG71 column. We believe that some nonpolar species (possibly metal humate complexes) may have reacted irreversibly with the nonionic resin, thereby contributing to the material loss. This conclusion is supported by (1) the reproducibility of the $\mathrm{Cr}$ data for sample $2830 \mathrm{~A}$, (2) the predictable performance of the cation exchange process (see Fig. 2), and (3) our observation that faint color remained on the CG71 column after elution of several samples (e.g., 2823A, 2862A). 


\section{CONCLUSIONS}

We have demonstrated the feasibility of determining undifferentiated metal concentrations in aqueous textile mill effluents using ICP-AES and a very simple digestion procedure. We have also showed that cationic metal species can be easily and accurately differentiated from other metal species using a sodium sulfonate cation exchange process. We lacked funds to completely develop a procedure that differentiates between organometallic species and other noncationic metal species, but the present procedure is adequate for identifying labile metal fractions.

Several improvements are possible. For example, our use of the nonionic resin column was not strictly necessary, but, as we have noted, a longer nonionic resin column would probably have separated organometallic species from those species not retained by the cation exchange resin. This separation would allow further differentiation of the total metal content and would facilitate a more refined approach to effluent toxicity testing and water treatment. Alternately, the present column arrangement could be used in combination with a more sensitive measurement technique (e.g., inductively coupled plasma mass spectrometry) to obtain equal or lower method detection limits with sample volumes less than $25 \mathrm{~mL}$. An examination of these alternatives was not possible within the frarnework of this study, but might be worthwhile once these techniques are implemented by the textile industry. 


\section{ACKNOWLEDGMENTS}

The work described herein was sponsored by the Textile Resource and Energy Conservation program of the AMTEX ${ }^{\mathrm{TM}}$ partnership. The authors wish to thank J. Silliman,

D. Alexander, H. Boyter, and P. Farber for their support. We also thank B. Luker, D. Bryant, and M. Edwards for their assistance in the laboratory. Argonne National Laboratory is operated by the University of Chicago for the United States Department of Energy under contract number W-31-109-ENG-38.

\section{REFERENCES}

1. R. Přibil, “Applied Complexometry," R. Chalmers, Ed., Pergamon, New York, pp. 6, 129, and 147 (1982).

2. H. Zhang and W. Davidson, Analytical Chemistry 67, 3391-3400 (1995).

3. J. C. Miller and J. N. Miller, "Statistics in Analytical Chemistry: 3rd Edition," Ellis Horwood PTR Prentice Hall, New York, pp. $62-65$ (1993). 


\section{Appendix A.}

\section{DETERMINATION OF TOTAL COPPER, COBALT, AND CHROMIUM IN WASTEWATER EFFLUENT}

\section{Equipment}

Safety glasses/goggles, lab coat/smock, acid-resistant gloves, laboratory fume hood, digital and/or volumetric pipettes, 100 -mL beakers, $25-\mathrm{mL}$ volumetric flasks, ribbed watch glasses, glass fiber or polycarbonate filters (below $2-\mu \mathrm{m}$ pore size), vacuum filtration apparatus, drying oven, hot plate, funnel and funnel stand.

\section{$\underline{\text { Reagents }}$}

ASTM type II reagent water (or better), concentrated nitric acid and concentrated sulfuric acid (both of high purity), standard solutions of copper, cobalt and chromium.

\section{Procedure}

1. Filter a 250-mL aliquot of a 24-hour composite effluent sample. (Note: preliminary filtration steps may be needed if the particulate content of the water sample is high. Samples containing suspended hydrophobic matter may not filter through polycarbonate.)

2. Quantitatively transfer a $25-\mathrm{mL}$ aliquot of the filtered sample into a clean, tared 100-mL beaker.

3. Place the beaker into a $105^{\circ} \mathrm{C}$ oven overnight. Remove the beaker, let cool, and weigh. Subtract the weight of the beaker to obtain the mass of residue.

4. Add $4 \mathrm{~mL}$ of $9 \mathrm{M} \mathrm{H}_{2} \mathrm{SO}_{4}$ to the beaker and wash the beaker walls with reagent water. Cover the beaker with a clean ribbed watch glass and place it on a hot plate set at medium-low heat in a laboratory hood. 
5. When the solution has dehydrated, apply medium-high heat until the solution fumes copiously. (Note: samples containing only inorganic matter will not fume strongly.) Then, slowly and carefully add three to five drops of concentrated $\mathrm{HNO}_{3}$, being careful to contain any spattering within the beaker.

6. Remove the beaker with the clear digest from the hot plate and allow it to cool. Then quantitatively transfer the sample to a volumetric flask and dilute to the mark with ASTM type II water. (Note: if the sample contained less than $250 \mathrm{mg}$ of residue upon drying, use a $25-\mathrm{mL}$ flask; otherwise, use a $50-\mathrm{mL}$ flask).

7. Submit the digested sample for ICP emission spectroscopy.

\section{Quality Assurance}

For one out of every ten samples to be analyzed, execute steps 1 and 2 of the procedure, but draw a total of four $25-\mathrm{mL}$ sample aliquots. To one aliquot, add $25 \mu \mathrm{g}$ each of $\mathrm{Cu}$ (II), Co (II), and Cr (III) prior to the execution of step 3. Then prepare all of the aliquots as instructed in steps 3 through 5. After the samples are transferred to their respective volumetric flasks (step 6), add $50 \mu \mathrm{g}$ each of $\mathrm{Cu}$ (II), $\mathrm{Co}$ (II) and $\mathrm{Cr}$ (III) to one of three unspiked digests and proceed with the final dilution.

Compare analyses of the two unspiked samples to assess method precision. Analyses of the two spiked samples shall be compared to assess preparative yield and measurement accuracy in the sample matrix. Comparing data from filtered and unfiltered water samples may also be of interest, but it is not obligatory. 
Appendix B.

DETERMINATION OF LABILE COPPER, COBALT, AND CHROMIUM IN WASTEWATER EFFLUENT

\section{Equipment}

Safety glasses/goggles, lab coat/smock, acid-resistant gloves, laboratory fume hood, digital and/or volumetric pipettes, PolyPrep ${ }^{\text {TM }}$ cation exchange columns (100-200 mesh Dowex AG50 X8 resin, BioRad catalog No. 731-6213), empty PolyPrep ${ }^{\mathrm{TM}}$ columns (BioRad catalog No. 7311550), 100-200 mesh AmberChrom ${ }^{\text {TM }}$ CG-71c resin (TosoHaas catalog No. 060640), column racks, assorted $(100-\mathrm{mL}, 50-\mathrm{mL})$ beakers, $25-\mathrm{mL}$ volumetric flasks, ribbed watch glasses, hot plate, funnel, and funnel stand.

\section{$\underline{\text { Reagents }}$}

ASTM type II reagent water (or better), concentrated nitric acid, concentrated sulfuric acid, concentrated hydrochloric acid (all of high purity), $1 \mathrm{M}(40 \mathrm{mg} / \mathrm{mL})$ sodium hydroxide, and methanol.

$\underline{\text { Procedure }}$

1. Condition one Dowex AG50 cation exchange column for each sample with $12 \mathrm{~mL}$ each of $4 \mathrm{M}$ hydrochloric acid, reagent water, and $1 \mathrm{M}$ sodium hydroxide. Then, wash each column with $16 \mathrm{~mL}$ of reagent water and set the columns aside.

2. Wash a batch of CG-71 polymer adsorbent resin thoroughly with methanol, then reagent water. Prepare an aqueous slurry of washed CG-71 resin. Pour about $5 \mathrm{~mL}$ of water into each empty Poly Prep column, then add $2 \mathrm{~mL}$ of resin slurry and allow the resin bed to settle. Agitate the resin bed as needed to eliminate air bubbles, and add slurry to achieve a final resin volume of $1.5 \mathrm{~mL}$. 
3. Adjust the column heads so that a minimum volume of water sits above the resin beds. Then, place the tail of an AG50 column directly above the head of each CG-71 column, and place a clean 100-mL beaker below the tail of the CG-71 column.

4. Draw a $25-\mathrm{mL}$ aliquot of filtered sample (see Appendix A) and transfer the aliquot to a clean $25-\mathrm{mL}$ beaker. Then transfer $5 \mathrm{~mL}$ of the sample aliquot to the head of the AG50 column, and allow both columns to flow freely. Quantitatively transfer the remaining sample to the AG50 column head in 2- to 5-mL increments. (Note: do not allow the CG71 column heads to go dry!) When the sample is exhausted, rinse the columns with $4 \mathrm{~mL}$ of reagent water. When the rinse is exhausted and the liquid has reached the level of the resin beds, stop the column flows, and set aside the CG-71 effluent for analysis.

5. Physically separate the columns. Place a clean $25-\mathrm{mL}$ volumetric flask below the tail of the AG50 column, and strip the column with four 4-mL aliquots of $4 \mathrm{M}$ hydrochloric acid ( $\sim 8 \mathrm{CVs})$. Dilute the AG50 column effluent to $25 \mathrm{~mL}$ using reagent water, and submit the diluted fractions for ICP emission spectroscopy. Place a clean $100-\mathrm{mL}$ beaker below the tail of the CG-71 column, and strip the CG-71 column with five 3-mL aliquots of methanol ( $10 \mathrm{CVs})$.

6. Cover the beakers with a ribbed watchglass, and bring the aqueous (from step 4) and methanolic (from step 5) CG-71 effluents to near dryness using a medium-low hotplate in a fume hood or a $105^{\circ} \mathrm{C}$ oven. Then, digest the residues according to the instructions given in Appendix A, steps 4 through 6, and submit the digests for ICP emission spectroscopy. 


\section{Quality Assurance}

The difference between total metal content (Appendix A) and the sum of metal content in each sample fraction should be statistically equivalent to zero. To assure this calculation is accurate, one reagent water blank should be carried through this procedure for every ten samples analyzed. The accuracy of the instrumental determinations should also be confirmed by preparing three spiked reagent blanks:

(1) $1 \mathrm{mg} / \mathrm{L}$ each of $\mathrm{Cu}, \mathrm{Cr}$, and $\mathrm{Co}$ in $2.5 \mathrm{M}$ hydrochloric acid

(2) $50 \mu \mathrm{g}$ each of $\mathrm{Cu}, \mathrm{Cr}$, and $\mathrm{Co}$ in $15 \mathrm{~mL}$ reagent water

(3) $50 \mu \mathrm{g}$ each of $\mathrm{Cu}, \mathrm{Cr}$, and $\mathrm{Co}$ in $15 \mathrm{~mL}$ methanol

Samples (2) and (3) should be digested using step 6 of this procedure, and all three solutions should then be analyzed (concurrently with the samples) to verify instrument calibration. A duplicate sample may also be prepared and analyzed to assess method precision, but it is not obligatory. 
Distribution for ANL/ACL-97/1

Internal:

I. Ahmad

I. Ambats

D. V. Applegate

J. G. Asbury

M. D. Atella

R. W. Bane

J. K. Bates

J. E. Battles

M. H. Bhattacharyya

S. K. Bhattacharyya

N. Bhatti

D. H. Bomkamp

A. S. Boparai

D. L. Bowers

B. S. Brown

F. A. Cafasso

Z. Cai

S. E. Carpenter

Y. I. Chang

L. L. Chromizky

R. F. Coley

J. T. Collins

E. J. Croke

J. C. Cunnane

L. W. Deitrich

J. C. Demirgian

C. B. Dennis

M. H. Derbidge

S. Dieckman

D. R. Diercks

M. L. Dietz

J. D. Ditmars

E. Dolecek

H. Drucker

F. J. Dudek

B. D. Dunlap

A. J. Dvorak

W. L. Ebert

M. D. Erickson

A. M. Essling

C. Foster

F. Y. Fradin
D. Freemon

B. Frost

N. W. Golchert

A. J. Goldman

D. G. Graczyk

J. W. Gramlich

D. W. Green (10)

D. M. Gruen

W. H. Gunther

Y. Halpern

J. E. Harmon

D. A. Haugen

R. R. Heinrich

J. E. Helt

W. F. Henning

J. E. Herceg

I. Hlohowskyj

E. P. Horwitz

H.-S. Huang

E. Huberman

E. A. Huff

D. R. Huff

A. B. Hull

M. J. Janik

D. O. Johnson

P. L. Johnson

T. F. Kassner

A. M. Kini

A. J. Kras

A. R. Krauss

J. R. Krsul

K. H. Leong

L. G. LeSage

M. A. Lewis

P. C. Lindahl

M. J. Lineberry

C. D. Livengood

F. Markun

V. A. Maroni

J. J. Marr

F. J. Martino

H. F. McFarlane
C. A. Melendres

C. N. Merrow

D. E. Moncton

L. R. Morss

T. P. Mulcahey

K. M. Myles

H. W. Myron

Z. Nagy

B. W. Nashold

L. A. Neimark

J. Noonan

J. W. O' Kelley

H. J. O'Neill

M. Oldham

Y. Orechwa

K. J. Parish

J.-H. Park

T. L. Patton

C. V. Pearson

D. R. Pedersen

J. P. Peerenboom

M. J. Pellin

R. Peters

M. Petrick

K. C. Picel

R. B. Poeppel

A. J. Policastro

Y. L. Qian

A. C. Raptis

D. M. Ray

G. T. Reedy

C. A. Reilly

M. J. Robinet

L. E. Ross

C. S. Sabau

N. A. Sacco-Gibson

N. F. Sather

W. W. Schertz

W. J. Shack

G. K. Shenoy

J. G. Sleeth

D. L. Smith 

D. L. Smith
J. D. Taylor
L. C. Walters
F. P. Smith
L. B. TenKate
D. W. Warren
L. L. Smith
T. TenKate
R. W. Weeks
R. K. Smither
R. J. Teunis
C. T. Snyder
C. E. Till
M. L. Wesely
V. C. Stamoudis
D. Tomasko
J. M. Williams
C. M. Stevens
Z. Tomczuk
W. E. Streets
A. Travelli
R. E. Winans
T. G. Surles
Y. Tsai
W. M. Swift
G. F. Vandegrift
B. S. Tani
B. Verhaaren
J. L. Woodring
J. J. Wray
R. A. Wynveen
TIS Files

\section{External:}

DOE-OSTI (2)

ANL-E Library

ANL-W Library

Manager, Chicago Operations Office, DOE

J. C. Haugen, DOE-CH

R. E. Lang, DOE-CH

A. L. Taboas, DOE-CH

B. J. Zeigler, DOE-CH

Chemical Technology Division Review Committee Members:

H. U. Anderson, University of Missouri-Rolla, Rolla, MO

E. R. Beaver, Monsanto Company, St. Louis, MO

D. L. Douglas, Consultant, Bloomington, $\mathrm{MN}$

R. K. Genung, Oak Ridge National Laboratory, Oak Ridge, TN

J. G. Kay, Drexel University, Philadelphia, PA

R. A. Osteryoung, North Carolina State University, Raleigh, NC

G. R. St. Pierre, The Ohio State University, Columbus, $\mathrm{OH}$

D. Alexander, Institute of Textile Technology, Spartanburg, SC

T. A. Baillieul, Battelle Columbus Laboratories, Columbus, $\mathrm{OH}$

P. Baisden, Lawrence Livermore National Laboratory, Livermore, CA

D. A. Bass, Doctor's Data, Inc., West Chicago, IL

T. Beasley, U.S. Environmental Measurements Lab., New York, NY

R. E. Berkeley, U.S. Environmental Protection Agency, Research Triangle Park, NC

R. Bisping, Fluor Daniel Hanford Inc., Richland, WA

H. Boyter, EarthTech, Charlottesville, VA

D. Bryant, Institute of Textile Technology, Charlottesville, VA

R. B. Chessmore, GEOTECH/GJPO, Grand Junction, CO

N. F. Christopher, Martin Marietta Energy Systems, Piketon, OH

C. E. Coffey, Augusta, GA

J. S. Crain, Union Carbide Corporation, South Charleston, WV (10)

P. T. Cunningham, Los Alamos National Laboratory, Los Alamos, NM

J. L. Daniel, Battelle Pacific Northwest Laboratory, Richland, WA

H. J. Dewey, USDOE, Office of Basic Energy Sciences, Germantown, MD 
J. G. Dorsey, Lockheed Martin Energy Systems, Inc., Oak Ridge, TN

P. A. Duhamel, USDOE, Office of Health and Environmental Research, Germantown, MD

M. Edwards, Milliken Research, Spartanburg, SC

C. Elly, U.S. Environmental Protection Agency, Chicago, IL

R. B. Fitts, Oak Ridge National Laboratory, Oak Ridge, TN

I. M. Fox, Woodridge, IL

C. W. Frank, USDOE, Office of Science and Technology, Washington, DC

J. Goldstein, USDOE, Office of Health and Environmental Research, Germantown, MD

B. T. Gregg, Allied Signal - Kansas City Division, Kansas City, MO

T. Grumbly, USDOE, Office of the Under Secretary, Washington, DC

D. Hunter, SSOC for USDOE, Radiological Laboratories, Golden, CO

M. Kelly, Sandia National Laboratories, Albuquerque, NM

J. T. Kiely, Doctor's Data, Inc., West Chicago, IL

W. Killian, Ferris State University, Big Rapids, MI

A. G. King, Westinghouse Hanford Company, Richland, WA

C. S. Leasure, Los Alamos National Laboratory,Los Alamos, NM

L. Lewis, Lockheed Martin Idaho Technologies, Idaho Falls, ID

B. Luker, Russell Corporation, Alexander City, AL

J. Mahoney, West Valley Nuclear Services Company, West Valley, NY

S. Messenger, Morton Arboretum, Lisle, IL

R. W. Morrow, Lockheed Martin Energy Systems, Inc., Oak Ridge, TN

L. Newman, Brookhaven National Laboratory, Upton, NY

R. D. Oldham, New Brunswick Laboratory, Argonne, IL

M. Pennington, Allied Signal Aerospace, Kansas City, MO

J. R. Phillips, Los Alamos National Laboratory, Los Alamos, NM

J. D. Pleil, U.S. Environmental Protection Agency, Research Triangle Park, NC

G. D. Robbins, Lockheed Martin Energy Systems, Inc., Oak Ridge, TN

R. S. Scott, USDOE, Office of Environmental Management, Washington, DC

J. Q. Searcy, Sandia National Laboratories, Albuquerque, NM

J. E. Silliman, Milliken and Company, Spartanburg, SC

J. Smith, University of Chicago, Chicago, IL

W. A. Spencer, Westinghouse Savannah River Company, Aiken, SC

F. D. Stevenson, USDOE, Office of Basic Energy Sciences, Germantown, MD

C. Stroup, Westinghouse Hanford Company, Richland, WA

L. Sygitowicz, Reynolds Electrical \& Engineering Co., Las Vegas, NV

R. Villarreal, Los Alamos National Laboratory, Los Alamos, NM

W. M. Walsh, Health Research Institute, Naperville, IL

R. J. Wingender, Dexter Corporation, Waukegan, IL 